\author{
Оксана Кіліченко, \\ кандидат педагогічних наук, доцент, \\ доцент кафедри педагогіки початкової освіти, \\ Прикарпатський національний \\ університет імені Василя Стефаника \\ (Івано-Франківськ, Україна) \\ Oksana Kilichenko, \\ Candidate of Pedagogical Sciences, Associate Professor, \\ Associate Professor of Pedagogy of Primary Education, \\ Vasyl Stefanyk Precarpathian National University \\ (Ivano-Frankivsk, Ukraine) \\ oksana.kilichenko@pnu.edu.ua \\ ORCID ID 0000-0001-5641-5481
}

УдК 37.018.2

\title{
ВИХОВАННЯ КУЛЬТУРИ СПІЛКУВАННЯ УЧНІВ МОЛОДШОГО ШКІЛЬНОГО ВІКУ В РІЗНОВІКОВІЙ ГРУПІ ПОДОВЖЕНОГО ДНЯ У ШКОЛАХ ГІРСЬКОГО РЕГІОНУ
}

Анотація. У статті розглянуто особливості формування і розвитку культури спілкування в дітей молодшого шкільного віку в різновіковій групі подовженого дня. Проаналізовано і визначено сутність поняття «культура спілкування». Визначено, що початкова школа є початком найважливішого для соціалізації особистості вікового періоду, оскільки сприяє формуванню групи подовженого дня як контактної групи, де діти засвоюють нові норми, цінності, стереотипи поведінки. Відзначено, що молодший шкільний вік $€$ найбільш соціально значущим і найбільш педагогічно підступним періодом, тому що відхилення у формуванні особистості часто маскуються захисною формою поведінки (ретельністю, слухняністю). Однак молодший шкільний вік є унікальним за наявністю досвіду довільного спілкування. Він стає базою культурних норм, які перевіряються пізніше в найрізноманітніших ситуаціях спілкування. Він $є$ сензитивним періодом формування культури спілкування. Усе це сприяє виробленню умінь розумно аналізувати, визнавати й оцінювати свої вчинки та дії, шукати і знаходити засоби досягнення поставленої мети, уміти переборювати перешкоди і труднощі.

Дослідження процесу формування культури спілкування було організоване в різновіковій групі подовженого дня в початковій школі гірського середовища. Визначено основні напрями формування культури спілкування в групі подовженого дня: розвиток культури вербального і невербального спілкування, боротьба із лихослів'ям, розвиток уміння уважного слухання.

Ключові слова: учні молодшого шкільного віку, різновікова група подовженого дня, культура спілкування, вербальне і невербальне спілкування, лихослів'я, уважне слухання.

\section{EDUCATION OF THE CULTURE OF COMMUNICATION OF PRIMARY SCHOOL STUDENTS IN THE EXTENDED DAY GROUP IN SCHOOLS OF THE MOUNTAIN REGION}

\footnotetext{
Abstract. The article considers the peculiarities of the formation and development of the culture of communication of children of primary school age in the different age group of the extended day. The essence of the concept of "culture of communication" is analyzed and defined.

It is determined that primary school is the beginning of the most important process for the socialization of the individual age period, as it contributes to the formation of an extended day group as a contact group where children learn new norms, values, stereotypes of behavior. The influence of the organization of the beginning on the level of group relations, the content of the social experience of each individual is noticed. It is noted that the primary school age is the most socially significant and the most pedagogically insidious period, because deviations in the formation of personality are often masked by a protective form of behavior (diligence, obedience). However, the primary school age is unique in the presence of experience of free communication. It becomes the basis of cultural norms, which are tested later in a variety of communication situations. It is a sensitive period in the formation of a culture of communication, as it is characterized by the following features: instinct, trust, pliability, the need for emotional contact with peers, the tendency to imitate. All this contributes to the development of skills to intelligently analyze, recognize and evaluate one's actions and deeds, to seek and find ways to achieve the goal, to be able to overcome obstacles and difficulties.

The different age of an extended day group is heterogeneous in its social situation and psychological characteristics. Therefore, there are two periods: adaptation (6-9 years) and pre-adolescent (9-10 years).

The study of the process of forming a culture of communication was organized in a different age group of an extended day in a primary school in a mountain environment. As our observations of students in extended day group and conversation
} 
with educators show, a characteristic feature of junior students' communication is their close communication with adults, which takes place in the learning process, at school (during the lessons and extended day group) and at home; informing adults about their affairs and the affairs of the class; asking adults for information on specific issues (we often call them "Chomuchki"). In elementary school, girls are more likely to initiate communication.

The main directions of formation of the culture of communication in the group of the extended day are defined: development of culture of verbal and nonverbal communication, struggle against profanity, development of ability of attentive listening.

Keywords: Elementary school students, age group of extended day, communication culture, verbal and nonverbal communication, profanity, attentive listening..

\section{INTRODUCTION}

Formulation of the problem. The challenges of the modern system of primary education are its democratization and humanization, which contributes to the growth of social contacts, including primary school students in this process. Therefore, teachers have a task to form a cultural, humanistically oriented, tactful, sociable personality. Of particular importance becomes studies of the peculiarities of communication of primary school students in the age group of the extended day, as previously analyzed mainly the communication of younger and older adolescents.

Analysis of scientific research. Theoretical principles of the communication process are defined in the works of: I. Bekha, O. Bodalyov, L. Bueva, O. Kyrychuk, J. Kolomynsky, O. Leontiev, H. Liimetz, A. Mudryka, N. Pobirchenko, V. Semichenko, V. Sukhomlinsky and others.

Sh. Amonashvili, K. Zhurba, B. Kobzar, V. Mukhina, G. Pustovit, O. Shestobuz and others studied the culture of communication of junior schoolchildren.

Relevant aspects of the research are: the study of the culture of language communication (N. Voloshin, O. Korniyaka, O. Protsenko), the culture of communication in extracurricular educational activities (K. Doroshenko, O. Matvienko, etc.).

At the present stage, attention is paid, especially during the Covid-19 pandemic, to the culture of virtual communication. "When communicating in a virtual environment, you should also remember that here, as in real life, there are rules of conduct, a kind of culture of virtual communication, which is also called netiquette" (Yanchuk, 2014, p. 3).

\section{AIM AND TASKS RESEARCH}

The purpose of the article is to determine the features and main directions of forming the culture of communication of primary school children in different age groups of the extended day. In accordance with the purpose, the main objectives of the study are defined: to analyze the concept of "culture of communication of primary school children", to determine the periods of development of children of different age groups, to specify the main directions of communication culture of primary school children in different age groups.

\section{RESEARCH METHODS}

To achieve this goal, methods of analysis and synthesis, abstraction, generalization, testing, questionnaires were used, which made it possible to analyze the theoretical foundations of communication culture of primary school children in different age groups and determine the main directions of this process.

\section{RESEARCH RESULTS}

Analyzing the concept of "culture of communication", we note that in pedagogical science it is often considered as a system of knowledge, skills and abilities to communicate, which according to the authors (V. Goreeva, O. Kulchytska, G. Chaika, T. Chmut, etc.) is created, accepted and implemented at a certain stage of development of society and reflected in the norms and rules of communication based on respect, friendliness and courtesy.

According to $\mathrm{O}$. Shestobuz views, the culture of communication of younger students with peers reflects the integrated quality of "personal knowledge, experience, interests and moral and ethical norms, which are manifested in communicative interaction" with a certain structure (Shestobuz, 2013).

N. Grabar, M. Mazorenko believe that the culture of communication promotes the development of the ability to establish feedback, the ability to respond to the feelings, thoughts, problems and concerns of another person (Grabar, Mazorenko, 2011).

We agree with the position of $\mathrm{S}$. Verbeschuk, that "The culture of communication of primary school children is considered as an integrated concept that includes socio-moral norms of behavior and culture of speech" (Verbeschuk, 2016, p. 185).

Analyzing modern research (I. Bekh, G. Genin, O. Korniyaka, O. Matvienko, V. Mukhina, A. Prokhorov, etc.) we note that the early school age is a sensitive period in the formation of a culture of communication. It is characterized by the following traits: instinct, trust, pliability, the need for emotional contact with peers, the tendency to imitate. All this contributes to the development of skills to intelligently analyze, recognize and evaluate their actions and deeds, to seek and find ways to achieve the goal, to be able to overcome obstacles and difficulties. Primary school is the beginning of the most important process for the socialization of the individual age period, which contributes to the formation of an extended day group as a contact group where children learn new norms, values, stereotypes of behavior. Note that not only the level of group relations, but also the content of the social experience of each individual depends on how this beginning is organized. However, psychologists call the primary school age the most socially significant and the most pedagogically insidious period, because deviations in the formation of personality are masked by a protective form of behavior (diligence, obedience) (Prokhorov, Genin, 1998).

On the other hand, the primary school age is unique in the experience of free communication. It becomes the basis of cultural norms, which are tested later in a variety of communication situations. In the group of the extended day the level 
of culture of schoolboys, its specificity and features of communication determines, defines character of communication of children.

However, the age group of an extended day is heterogeneous in its social situation and psychological characteristics. It highlights certain stages, periods, which, given the psychological and pedagogical characteristics, can contribute to the realization of the potential of the children's group, but can inhibit the formation of a culture of communication.

According to the concept of A.V. Petrovsky we distinguish two periods: adaptive (6-9 years) and pre-adolescent (9-10 years).

Each period is characterized by the peculiarities of children's communication with adults and peers, which are determined by the social position and the impact of educational activities on the communication system in the age group of an extended day.

A characteristic feature of the adaptation period (6-9 years) is a new stage in the development of self-awareness ("I am a student"), when the child tries on the first social role, accompanied by a certain psychological alienation from the family. It is during this period that the younger student creates an image of himself positive. The educator of extended day group has a task: to form adequate self-esteem in children and to save and maintain an optimistic, realistic and active attitude to their shortcomings. There is a change of children's alternating positions: "I and society" and "I am in society". Note that in the Standard educational program developed under the guidance of O. Savchenko (2019), identified the following content lines, which in our opinion, help the younger student in the organization of communication: "Man" (knowledge of themselves, their capabilities; healthy and safe behavior); "Man among men" (standards of behavior in the family, in society; moral norms; skills of coexistence and cooperation); "Man in society" (civil rights and responsibilities as a member of society. Knowledge of their land, history, symbols of the state. The contribution of Ukrainians to world achievements); "Man and the world" (tolerant attitude to the diversity of the world of people, cultures, customs) (Typical educational program, 2019, p. 38).

A characteristic feature of this period is the increase in the authority of teachers, whose actions and deeds are copied, imitated by children.

On the other hand, children's communication is "imposed" and the intensity of children's communication is often underestimated.

Thus, as our research shows, the adaptive period is characterized by the formation of the subjectivity of the younger student, and the content of communication is determined by learning and play activities. It is sensitive to the following tasks: teaching children to cooperate in a group; forming a culture of dialogue; adherence to a culture of criticism; assimilation of etiquette norms and formation of skills to adhere to them.

In addition to the status "I am a schoolboy", the status of "I am a friend" is one of the peculiarities of the preadolescent period. It is a period when a child seeks to find his place in the world of adults, as a result of which some of them have a crisis of self-esteem. Personal relationships between children become more differentiated and can arise not only through joint educational activities, but also depending on moral and religious positions. Informal communication is playing an increasingly important role in establishing relationships between children.

The pre-adolescent period is sensitive to the following tasks: raising the moral and reflexive level of children; development of the group - the leader; children's awareness of interpersonal communication as a great value; propaedeutics of business communication culture. Thus, in the process of organizing communication in different age extended day group, the educator must pay attention to the features of the two types of communication, which reflect the adaptation and adolescence.

The study of the process of forming a culture of communication was organized in the multi-age extended day group in Yasinyanska Secondary School of the first grade №4, Yasinya village, Zakarpattia region, where 30 children of 2 nd, 3rd and 4th grades study together (educator Dyachuk I.I.).

As our observations of extended day group students and educators 'surveys show, a characteristic feature of junior school students' communication is their close communication with adults, which takes place in the following areas: in the learning process, at school (during the lessons and extended day group) and at home; informing adults about their affairs and the affairs of the class; asking adults for information on specific issues (often called Chomuchki). In elementary school, girls are more likely to initiate communication.

To determine the directions of formation of the culture of communication, we analyzed the levels of formation of the culture of communication of extended day students for children of 2nd grade and 3-4th grade.

In the age group of the extended day Yasinyanska Secondary School of the 1st grade №4, v.Yasinya, Zakarpattia region, there were 10 children of the 2 nd grade. The initial (low) level is inherent in 2 pupils and the criteria reflect the following characteristics: formed selfish attitudes, deformation of the moral development of the individual. Children communicate only for self-affirmation, to humiliate others, or to satisfy lowly needs. The average level is typical for 4 children who behave differently in different areas of communication. 3 pupils have a high level of communication and they are characterized by a developed moral sphere, they have sufficient dialogic skills, but in communication often play a passive role, as they do not have the criteria for its evaluation. A very high level of culture of communication is characteristic of 1 child, which is characterized by a humanistic attitude in communication.

There are 20 children of 3-4 grades in the extended day group. The initial (low) level of formation of the culture of communication is peculiar to 4 pupils. They have no interest in communication, they are passive, they do not have selfcontrol. 8 pupils have an average level. They begin to develop reflection as a way of self-knowledge and self-education. For 4 pupils - a high level of culture of communication. It is manifested in the successful attempts of children to take an active 
communicative position in the system of interpersonal communication. 4 pupils have a very high level of communication culture, which is manifested in children with the emergence of the need for self-improvement in communication.

Organizing the development of a culture of communication in the age group of an extended day, it is necessary to pay attention to the following points.

In the first days of the extended day group of different ages, when children enter the system of communicative relations, the teacher must create conditions for their self-actualization, self-presentation. To this purpose, children are given tasks: to compose short oral stories about themselves, the events of their lives, their interests. Pupils were asked to bring their favorite toys and talk about them. Other children at this time listened carefully and asked clarifying questions. Note that when asking questions, children had to avoid repetition, stereotypes. Many children have a reason to come and get acquainted. It provided an equal opportunity to express himself, encouraged withdrawn, unsociable, shy children, and calmed hyperactive, ill-behaved, or infantile children a little.

Finger toys (animals) were also used for this purpose.

It is necessary to explain to children the content of some rules of communication. In particular, the basic rules include:

1. Call comrades by name, do not use nicknames.

2. Do not ridicule the mistakes and shortcomings of friends, do not tease, do not quarrel, do not grimace, do not gossip.

3. Allow conflict situations, discussions, which are aimed at discussing and correcting their own mistakes. It is important to teach children to be able to sincerely apologize and forgive.

4. Forming a culture of criticism.

As our research has shown, children want to communicate with more active and with a sense of humor children.

In order to form a culture of communication in the extended day group work was organized in the following areas:

1. Development of the culture of verbal communication and, in particular, dialogical communication;

2. Development of a culture of nonverbal communication;

3. Fighting gossip.

4. Development of the ability to listen carefully.

One of the tasks is the formation and development of dialogic skills and, above all, the ability to ask questions.

Therefore, "Chomuchki clubs" should be introduced into the work of extended day group. To this purpose, we suggest that children write their questions on slips of paper and drop them in the "mailbox". Then you can get a personal response from the educator or from specially created groups of children. It is important to organize a discussion of issues. This form of educational work contributes to the activation of children's cognitive activity (search for information for questions and answers), but also allows each participant in the dialogue to understand the complexity and importance of accurate questioning, formulation of answers.

We divided the questions into three groups: Questions for the sake of questions; clarifying questions supplement the content of educational material; issues of a problematic nature.

Children often had difficulty asking problematic, creative questions. One of the obstacles to creating a culture of behavior was the use of profanity by children.

Observation of extended day group pupils allowed to draw conclusions: $76 \%$ of the children in the group slander, $23 \%$ of the studied children curse. According to $51 \%$ of surveyed students, their parents slander about them. However, only $12 \%$ of parents surveyed admitted that they could use obscene language. Unfortunately, $10 \%$ of students surveyed said they had heard slander from teachers. $40 \%$ of teachers admitted that they slander students. The analysis of observations and polls showed that most often it is not the act that is condemned, but the individual in general, who is ridiculed and humiliated. Analysis of scientific works (Shirokoradiuk, 2001; Verbeschuk, 2016) shows that student profanity can be classified into the following blocks: "body", "appearance", "temperament", "character", "mind", "nationality", "wildlife "," social status "," crime ". When organizing the fight against gossip, we pay attention to the following points. Six-yearolds use teasers, students in grades 2-3 often take painfully perceive words that devalue them as an arbitrary assistant and executor of the teacher's requirements. Fourth graders are adolescents and are sensitive to words that belittle their adulthood

When organizing correctional and preventive work, it is worth paying attention to the following key points:

1. The use of profanity among students is a "living" phenomenon and it is impossible to prohibit it, so it is necessary to form a moral and psychological position in children regarding its rejection and condemnation. Therefore, it is worth using small thematic conversations.

2. It is necessary to get acquainted with the elements of the technique of "I-messages" and "You-messages", which help to verbalize negative emotions, avoiding gossip.

3. Using dramatization techniques to play situations.

4. The use of relaxation exercises and exercises that develop the ability to recognize other people's emotions, to develop empathy.

In order to develop a culture of nonverbal communication, we offer children the following exercises:

1. Children stand in a circle and with the help of gestures and facial expressions should greet the next participant in the game;

2. Congratulate the child on his birthday, using only gestures and facial expressions;

3. With the help of gestures and facial expressions ask to give way, a place at the desk;

4. Using gestures and facial expressions to parody the morning of the student. 
5. "Read" facial expressions and movements (According to Allan Pisa's book "Sign Language").

In order to develop verbal and nonverbal communication, you should use a series of communicative games on the following topics: "Say hello to an adult", "Say hello to a student from your group who is studying in junior class", "Say hello to a student from your group who is studying in senior class", " Say hello to a classmate". To this end, we divide the children of 3 (4) groups according to the classes and offer to greet in turn. The team that greeted last will win.

An important direction in the formation of a culture of communication is the development of children's "attentive listening". Children always have a lot of questions. They, listening to the explanations of the educator, constantly update the information about the necessary actions. For example, "Where should I write?", "Where is my ruler?", "What should I draw?" etc.). And when children from different classes are in the group for an extended day, there can be chaos, disorganization of the group, irritation of the teacher. And often reaction is a ban on questions. As our observations show in such groups, children are forbidden to ask any questions. The result is silence on the teacher's question "Does anyone have any questions?" Therefore, it is advisable to use a system of special tasks that remove the "ban" on asking. For example, during the organization of educational conversations there used techniques: "I do not believe", "Prove". The essence of these techniques is that the designated children have the right to use these phrases during the explanation or discussion.

We introduce children to the techniques of active listening and develop the ability to use them. Therefore, in the first lessons we discuss the basic techniques of active listening. On the board we hang 2 reference diagrams, which the children take turns discussing and commenting on.

The first reference scheme includes the following questions-tasks: remember, name and analyze your listening habits; model the pose "I listen carefully"; explain the technique of "Be attentive", how to focus attention.

The second reference scheme includes the following questions-tasks: the most common mistakes are: interruption of the interlocutor; asking many questions. It is important to teach children to analyze different communication situations. To this end, it is necessary to define with children the criteria for evaluating questions in terms of productivity or unproductiveness of dialogue. Therefore, it is advisable to organize a system of educational activities, united by one theme "Alphabet of communication culture", which we implemented through educational activities in the form of correspondence trips "In the land of magic words", role-playing games "Learning to speak correctly", "Are you a polite Ukrainian" , "We invite polite friends to the circle", "Responsive boy", etc., discussion of problems: "Is it easy to be polite?", "A person begins with good?", a virtual journey "To the land of magic words".

\section{CONCLUSIONS AND PROSPECTS OF FURTHER RESEARCH}

Thus, the effectiveness of pedagogical activities to form a culture of communication of primary school students depends to a greater extent on the forms of organization of various activities of children. However, in shaping practice it is also necessary to take into account the preconditions created by family upbringing, school life situations, which is the child's experience of communication with adults and peers and, of course, the level and specifics of personal and professional development of teachers.

As we have noted, the problem of forming a culture of communication of the student acts as a multifaceted, diverse and covering all areas of the child's life. Therefore, educators should pay attention to the problems of lack of discipline in primary school students, the development of independence and cognitive activity of children in extracurricular activities, the problems of adaptation of students to new learning conditions, and others.

\section{REFERENCES}

Verbeshhuk, S.V. (2016) Formuvannja movlennjevoji kuljtury uchniv pochatkovoji shkoly v procesi literaturnogho chytannja [Formation of speech culture of primary school students in the process of literary reading]. Dysertacija na zdobuttja naukovogho stupenja kand.ped.nauk, Ivano-Frankivsjk.

Ghrabar, Gh., Mazorenko, M.O. (2011) Kuljtura spilkuvannja [Culture of communication]. Kharkiv: KhNTUSGh.

Kuljtura virtualjnogho spilkuvannja: metodychni porady [The culture of virtual communication: guidelines] / Ukladach Janchuk A.M. (2014). Upr. kuljtury, nacionaljnostej ta relighij Khmeljnyc. oblderzhadmin; KhOUNB im. M. Ostrovsjkogho. Khmeljnycjkyj.

Prohorov, A., Genin, G. (1998) Osobennosti psihologicheskih sostojanij mladshih shkol'nikov [Features of the psychological states of primary schoolchildren]. Voprosy psihologii, 4. 42-53.

Typova osvitnja proghrama [A typical educational program] / rozroblena pid kerivnyctvom Savchenko O.Ja. Zatverdzhena Nakazom Ministerstva osvity i nauky Ukrajiny vid 06.10.2019 roku № 1272. URL : https://mon.gov.ua/storage/app/media/zagalna\%20serednya/programy-1-4klas/2019/11/1-2-dodatki.pdf.

Shestobuz, O.S. (2013) Formuvannja kuljtury spilkuvannja molodshykh shkoljariv z odnolitkamy u pozaklasnij dijaljnosti [Formation of the culture of communication of junior schoolchildren with peers in extracurricular activities]. Avtoreferat. Umanj.

Shyrokoradjuk, L.A. (2001) Psykhologho-pedaghoghichni prychyny lykhosliv'ja ta osoblyvosti jogho projavu u shkiljnomu seredovyshhi[ Psychological and pedagogical causes of profanity and features of its manifestation in the school environment]. Avtor.dys. na zdobutja naukovogho stup. kand.psykh.nauk. Kyiv. 